\title{
Fenntartható kétnyelvüség
}

1. Bevezetés. A tanulmány arra a kérdésre ad választ, hogy mi a fenntartható kétnyelvüség (a továbbiakban: FK). A jelenség a közösségi kétnyelvűség időhöz köthető müködését érinti, és az 1990-ben elindított és azóta folyamatosan zajló magyarországi szociolingvisztikai vizsgálatok összefoglaló eredményeként értelmezendő. ${ }^{1}$

A szakirodalom a közösségek kétnyelvüségét az idő aspektusából kiindulva két típusba sorolja: ins ta bil és s ta bil (FISHMAN 1968; GAL 1979: 2). Az instabil kétnyelvüség folyamata nyelvcseréhez vezet, ami WEINREICH (1953: 68) megfogalmazása szerint akkor következik be, ha a közösség egy nyelv szokásos használatáról áttér egy másik nyelv használatára. Az eddigi kétnyelvüségi kutatások a nyelvcsere kutatására összpontosítva a folyamat nyelvészeti oldalát és társadalmi motiváltságát vizsgálták. A legismertebb és leggyakrabban idézett nyelvcserekutatásról SUSAN GAL (GÁL ZSUZSA) könyvében (1979) olvashatunk, melynek eredményei további hasonló vizsgálatok elindítását inspirálták szerte a világban, köztük a jelen tanulmányban bemutatott kutatásokat is.

A nyelvcsere folyamatának időbeli dimenziója közösségenként eltérö lehet. Emigráns közösségekben a nyelvcsere többnyire három generáció alatt zajlik le. HAMERS és BLANC (1989: 176) e háromgenerációs modellt a következőképpen mutatja be. Az első generáció vagy egynyelvü (a kisebbségi csoport nyelvét ismerve kizárólagosan: $\left.L_{x}\right)$, vagy pedig anyanyelvén domináns kétnyelvủ $\left(L_{x}>L_{y}\right)$. A második generációra a kétnyelvüség a jellemző. Végül a harmadik generációt a második nyelv dominanciája $\left(\mathrm{L}_{\mathrm{x}}<\mathrm{L}_{\mathrm{y}}\right)$ vagy kizárólagos ismerete jellemzi $\left(\mathrm{L}_{\mathrm{y}}\right)$. Ezt a háromgenerációs modellt látszanak igazolni KonTRA (1990) South Bend-i, BARTHA (1993) detroiti és FENYVESI (1995) mckeesporti vizsgálatai. Esetenként a három generációt követheti egy olyan generáció is, amelynek tagjai újratanulják a közösség első nyelvét. Nem ennyire pontosan meghatározható a generációk összefüggésében az (ős)honos kétnyelvü közösségek nyelvcserefolyamata. Többek között ennek kiderítésére lett megtervezve az a máig egyetlen országos - hat nemzetiségi közösség egy-egy kiválasztott kétnyelvű településén végzett - öszszehasonlító szociolingvisztikai vizsgálat (MaBiLing.), melynek átfogó elméleti és módszertani leírását BARTHA (2003) ismerteti, és amelynek néhány kutatási eredményéről az alábbiakban számolunk be.

\footnotetext{
${ }^{1}$ A tanulmány egy longitudinális és egy közösségeket összehasonlító szociolingvisztikai kutatás eredményeire épül. A Variabilitás és változás: a nyelvcsere vizsgálata látszólagos és valóságos időben címü OTKA K 81574 (2010-2013) és az ezt megelőző OTKA T030305 (1999-2002) pályázat támogatásával az MTA Nyelvtudományi Intézetében készült (vö. LongBiLing. kutatás, pl. BORBÉLY 2014). A nyelvi másság dimenziói: A kisebbségi nyelvek megörzésének lehetőségei címü projektum konzorciumvezetője BARTHA CSILLA volt, témavezetője BORBÉlY ANNA, és az NKFP 5/126/2001. számú pályázat anyagi támogatásával készült (vö. MaBiLing. kutatás, pl. BARTHA 2003). Ezúton is szeretném köszönetemet kifejezni VARGHA ANDRÁSnak a tanulmányban ismertetett öszszetett statisztikai számításokért és egyéb tanácsaiért.
}

Magyar Nyelv 112. 2016: 63-73. DOI: 10.18349/MagyarNyelv.2016.1.63 
A stabil kétnyelvü közösségek - ellentétben az instabil kétnyelvü közösségekkel - megőrzik az általuk használt nyelveket. Számtalan körülményből fakadóan a nyelvek funkcionálisan és szabályszerüen elkülönülnek, amit FISHMAN (1971: 75) - FERGUSON (1959) nyomán - diglossziaként jellemzett. Ezzel összhangban a nyelven belüli és a nyelvek közötti viszonyok strukturálása a jelen folyóirat lapjain is teret nyert (1. KISS 1994). SCHIFFMAN (1993) a diglossziát és a triglossziát több közösségben vizsgálva arra a következtetésre jutott, hogy kevés igazán stabil eset van. Ezek közül a Luxemburgban megvalósuló stabil triglossziát mutatja be, melynek sikerét öt körülménnyel hozza összefüggésbe. A triglosszia törvényileg támogatott; a nyelvek funkcionálisan elkülönülnek; a nyelvpolitika a triglosszia földrajzi elterjedését segíti; társadalmilag teljesen elterjedt, hiszen minden állampolgár beszéli a nyelveket és változataikat; és a beszélőközösség és nyelvi kultúrája homogén (SCHIFFMAN 1993: 136-138). A korábban stabilnak hitt diglosszikus közösségekre is inkább az instabilitás a jellemző, aminek - SCHIFFMAN (1993: 115) szerint - az a legföbb oka, hogy a nyelvek ,ereje nem egyenlö”.

A kétnyelvű közösségi kutatások tehát zömmel az instabil állapotokra összpontosulnak, ahol az idő aspektusa alapvető. Az instabil kétnyelvüségben egy időben a generációkat és azon belül az egyéneket összehasonlítva kiderül, hogy kétnyelvüségük eltér egymástól. Nagy általánosságban fogalmazva, az eredetileg A nyelven egynyelvü közösség A és B nyelven kétnyelvűvé válva eljut egy olyan állapothoz, amikor a közösség egyre kisebb része leginkább az A nyelvet, a másik része többnyire A és $B$ nyelvet is, a harmadik része pedig leginkább vagy kizárólag a B nyelvet beszéli. Ennélfogva bizonyos egyének az instabil kétnyelvüségi helyzetben, ugyanabban az időben képesek, mások pedig nem képesek fenntartani kétnyelvüségüket. Ebből az idővel is összefüggő megfigyelésből indulunk ki, amikor a vizsgálati kérdések megfogalmazásakor arra összpontosítunk: hogyan müködik, mi határozza meg és hogyan kutatható az instabil kétnyelvü helyzetben regisztrálható FK jelensége. A bemutatott kutatások a múlt század utolsó évtizedére és századunk első évtizedére terjednek ki.

2. Hat kétnyelvü közösség összehasonlítása. Ebben a részben az FK-t a magyarországi nemzetiségek (etnikai/kisebbségi/kétnyelvü közösségek) egy-egy településen élő közösségeiben vizsgáljuk. A kutatások olyan településeken készültek, ahol az (ős)honos lakosság a múltban (többségében) magyarul nem beszélö csoportot alkotott. ${ }^{2}$ Ezeken a településeken egy, két vagy több évszázadra visszatekintve a beást, a németet, a romanit, a románt, a szerbet vagy a szlovákot beszélték. A kétnyelvü közösség terminus a továbbiakban konkrétan tehát egy olyan csoportra vonatkozik, amely egy településen élő nemzetiségi közösség tagjait foglalja magában, akiknek nyelvhasználata nem csupán egy nyelvet és az azon belüli területi,

${ }^{2}$ A vizsgált települések a következők voltak: Mánfa és Bogyiszló (beások), Tarján (németek), Mezőtúr (romák), Kétegyháza (románok), Pomáz (szerbek) és Tótkomlós (szlovákok). Ezúton is megköszönöm az adatgyüjtést a következő kutatóknak és terepmunkásoknak: ORSÓs ANNA, EGREGYI BORBÁlA (beások); ERB MARIA (németek); KISS ANDREA (romák); ABRUDÁN MÁRIA (románok); SZIMICS MILOSNÉ (szerbek); HORNOKNÉ UHRIN ERZSÉBET, TÓTH SÁNDOR, TUSKA TÜNDE és ZSILÁK MÁRIA (szlovákok). 
társadalmi és szituációs változatokat érinti, hanem egy másik nyelvet és változatait is (pl. kétegyházi románok). Ritkán, tágabb értelemben pedig utalhat az „egész” nemzetiségi csoportra (pl. magyarországi román nemzetiség) is. (A kétnyelvü és többnyelvü közösségek terminusról egy általánosabb áttekintést ad DORIAN 2004.)

A MaBiLing. kutatás vizsgálatai többek között a kétnyelvü közösségek nyelvválasztására, nyelvi attitüdjeire, nyelvtudására terjedtek ki (vö. BORBÉLY 2014: 81-121). Ezek a kétnyelvüségi jelenségekre fókuszáló és egységes módszerrel készült kérdőíves elemzések azt mutatták, hogy a hat közösség összehasonlításában szabályszerü e l t é r é s e k és h a s o n ló s á g o k vannak.

A nyelvválasztást firtató kérdések a mindennapi kommunikációt lefedő 22 nyelvválasztási szituációra vonatkoztak. A válaszokból kiderült, hogy a szerb és a roma közösségben a nyelvek választása kiegyenlítettebb, mint a szlovák és a román, és még inkább, mint a beás és a német közösségben. A kiegyenlített nyelvválasztás megvalósulhat úgy is, hogy egy-egy nyelvválasztási színtéren az egynyelvü beszédmód dominál (pl. szerb egyházi szertatás és magyar kórházi ellátás), illetve úgy is, hogy a kétnyelvü beszédmód érvényesül (pl. szerb-magyar kéttannyelvü oktatás). A szerbeknél mindig szerbül beszélnek a vizsgált 22 nyelvválasztási szituációban átlagosan 50\%-ban, a romák pedig mindig romani nyelven beszélnek átlagosan 43\%-ban. A beások a 22 nyelvválasztási szituációban átlagosan csak 18\%-ban adták meg a mindig beásul válaszkategóriát, a németek pedig csak 14\%ban választották a mindig németül válaszkategóriát (vö. BORBÉLY 2014: 93). Az eredmények alapján tehát kialakult egy sorrend aszerint, hogy a közösségekben a két nyelv használata hol tartható fenn leginkább: 1. romák, 2. szerbek, 3-4. románok és szlovákok, 5 . beások, 6 . németek. Ennek a sorrendnek a fordított iránya pedig azt mutatja, hogy mely közösségek járnak elöl a nyelvcsere folyamatában: időben hol kezdődött el a leghamarabb, vagy melyik közösségben a leggyorsabb. A kutatás további részeiben a nyelvválasztás szabályszerüségei az FK jelenségére irányították a figyelmet, és viszonyítási alapként (objektumként) szolgáltak a nyelvi attitüdök és a nyelvtudás vizsgálati eredményeinek értelmezésekor. Hipotézisünk szerint az FK egy vonatkozási rendszer, melyben a nyelvválasztás az a viszonyítási objektum, amely az FK szempontjából releváns nyelvi attitüdök és nyelvtudás minőségének kiderítését szolgálja. Az FK vonatkozási rendszerében azoknak a kétnyelvü közösségeknek a nyelvi attitüdjei és nyelvtudása kap figyelmet leginkább, amelyekben a két nyelv választása kiegyenlített. Ugyanígy fontos az is, hogy azokban a kétnyelvü közösségekben, ahol az FK kevésbé érvényesül, ugyanúgy eltérőek-e a nyelvi attitüdök és a nyelvtudás, akár a nyelvválasztás.

Négy (emocionális, esztétikai, pragmatikai és kompetenciális) nyelvi attitüdöt vizsgálunk meg, hogy kiderítsük: milyen eltérések és hasonlóságok tapasztalhatók a vizsgált közösségekben. Elsőként azt volt tanácsos kideríteni, hogy milyen attitüdök jellemzik azt a kétnyelvü közösséget (pl. a szerbeket), ahol a mindennapi kommunikációban a nyelvek választása kiegyenlítettebb. Az eredmények igazolták a feltételezést, mert a szerb közösségben másféle válaszokat kaptunk, mint a másik három vizsgált közösségben (németek, románok és szlovákok). A szerb közösségben pozitív nyelvi attitüdök voltak regisztrálhatók mind a nyelvjárási, mind a sztenderd változatok irányában. Ezzel szemben a szlovákok és a románok 
a sztenderd változathoz kapcsoltak pozitív válaszokat, míg a németek a négy attitüdváltozó szerint hol a sztenderdhez, hol a nyelvjáráshoz. A nyelvi attitüdökre jellemző az FK vonatkozási rendszerében a következő: ahol kiegyenlítettebb a nyelvek használata, ott a kisebbségi nyelven belüli változatokról - a nyelvjárásról éppúgy, mint a sztenderdről - egyformán pozitív nyelvi attitüdök alakulnak ki és stabilizálódnak (vö. szerbek).

A román és a szlovák közösség mind a nyelvválasztás, mint a nyelvi attitüdök szerint hasonló eredményeket produkált; a továbbiakban a nyelvtudásukat hasonlítjuk össze. Eredményeink szerint a román és a szlovák közösségben a nyelvtudás is hasonló mintázatot mutat. Mindkét közösségben jobban tudják a magyar nyelvet, mint a román, illetve szlovák területi nyelvváltozatot. A legalacsonyabb szinten mindkét közösségben a nemzetiségi nyelv ${ }^{3}$ sztenderd változatát ismerik. A román és a szlovák adatokat további négy magyarországi kétnyelvü közösség eredményeivel összehasonlítva kiderült, hogy az adatközlök önbecslése szerint ők átlagosan jobban beszélnek magyarul, mint saját nemzetiségi nyelvükön. Az elemzések azt mutatják, hogy a magyar nyelv tudását mind a hat közösségben magasabbra értékelik, mint a közösségi nyelv területi változatáét. A nemzetiségi nyelv tudását az a közösség értékelte a legmagasabbra, amelyikben a nyelvválasztás kiegyenlítettebb; magyar nyelvtudását pedig az a közösség értékelte a legmagasabbra, amelyik a leggyakrabban használja a magyar nyelvet. Az eredmények alátámasztották a hipotézist: a kétnyelvü közösségben beszélt nyelvek választása az FK vonatkozási rendszerében viszonyítási objektumként szolgál mind a nyelvi attitüdök, mind a nyelvek tudásszintjének tekintetében.

Az FK vonatkozási rendszerébe bevont nyelvi folyamatokat a társadalmi folyamatok és az ebből fakadó közösségi folyamatok együttesen, de közösségrölközösségre másként determinálják, mivel a hat közösségre vonatkozó FK szerinti sorrendet az ezekre a folyamatokra kialakított közösségi stratégiák alakítják. Az eredmények összegzéseként körvonalazódik a kétnyelvű közösségekre vonatkozó fenntartható kétnyelvüségi modell (FKM, lásd 1. ábra). Bár az FKM olyan kétnyelvűségi jelenségekre összpontosít, mint nyelvválasztás (nyelvhasználat), nyelvtudás és nyelvi attitüdök, nem zárhatók ki további olyan nyelvi tényezők sem, mint például a közösségben ismert nyelvi ideológiák. Az FKM ábrán a kétnyelvüségben érintett nyelvekre a hamersi-blanci modell elemeit használom fel

${ }^{3}$ Nyelvcserehelyzetben a közösség egészére általánosan, illetve egyes tagjaira vonatkozóan az anyanyelv kategória használata nem egyértelmű. Maguk a beszélők is ezt erősítik meg. Például egy interjúból, a legutóbbi népszámlálásról beszélgetve kiderült, hogy feleség és férj 2011-ben az anyanyelvre és a nemzetiségre utaló KSH-kérdésekre másképpen válaszolt. Míg a feleség román anyanyelvünek és magyar nemzetiségünek, addig férje magyar anyanyelvünek és román nemzetiségünek vallotta identitását; miközben felnőttkoruktól mindketten évtizedek óta csak azokkal beszélnek románul, akik nem beszélik a magyar nyelvet, illetve a hozzájuk románul szóló kétnyelvűek kérdéseire is mindig magyarul válaszolnak. Mondhatjuk-e ebben az esetben, hogy a román az anyanyelvük? Közelebb járunk az igazsághoz, ha esetükben első nyelvként a románt, második nyelvként a magyart jelöljük meg. Ezért használom a nemzetiségi nyelv kategóriát, így mindig egyértelművé téve, hogy a valamikori közösség tagjainak anyanyelvére utalok. 
$\left(\mathrm{L}_{\mathrm{x}}\right.$ és $\left.\mathrm{L}_{\mathrm{y}}\right)$. Ezek a következő nyelvpárokra vonatkoznak: beás-magyar, németmagyar, romani-magyar, román-magyar, szerb-magyar és szlovák-magyar. A modell kitér az $\mathrm{L}_{\mathrm{x}}$-en belüli változatok viszonyára is (ahol ez releváns), vagyis a tarjáni német, kétegyházi román, pomázi szerb, tótkomlósi szlovák területi nyelvváltozatokra és a sztenderd változatokra. Ezért az x nyelven belül jelöltem ezeket a nyelvváltozatokat is: $\mathrm{a}+\mathrm{b}\left(\mathrm{L}_{\mathrm{x}(\mathrm{a}+\mathrm{b})}\right)$. Bár a kutatás nem terjedt ki a magyar nyelvváltozatok tanulmányozására, az 1 . ábra ezek használatát csupán ezért nem zárja ki. A modell szerint tehát a kétnyelvüségben érintett nyelveknek - e nyelvi jelenségekkel összefüggésben - szükséges egy kiegyenlített, mellérendelt, nem hierarchikus viszonyrendszert kialakítani, stabilizálni és fenntartani ahhoz, hogy az FK mint állapot létrejöjjön és - ameddig lehetséges - fennmaradjon.

\section{1. ábra}

A fenntartható kétnyelvüség modellje (FKM)

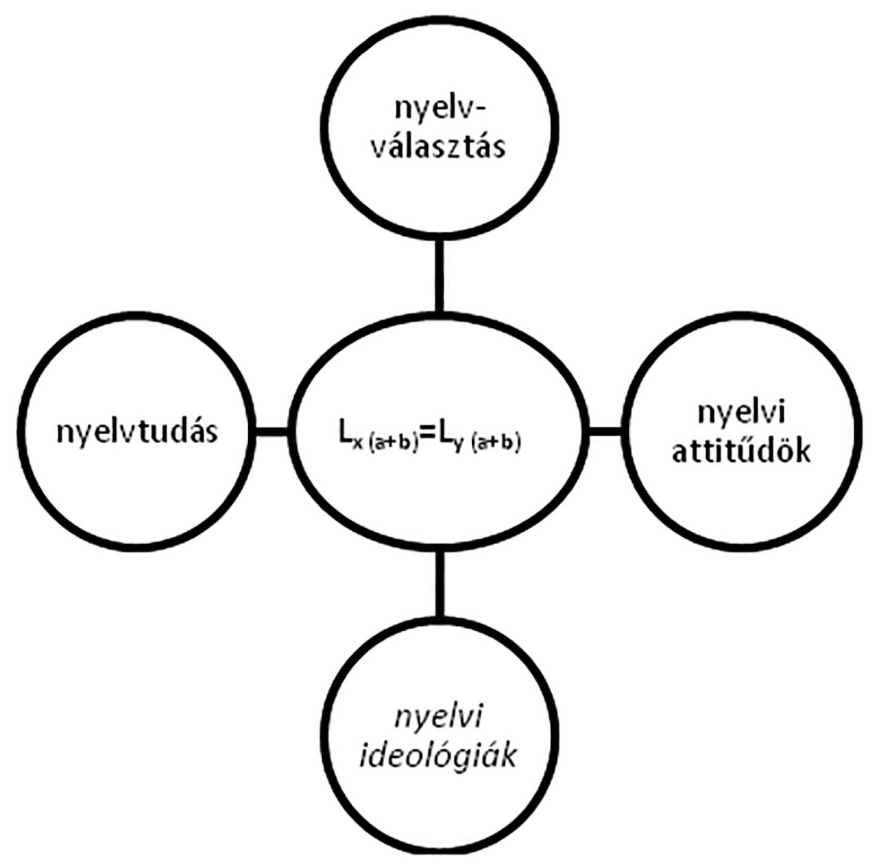

Az FKM pillérei kizárólag nyelvi viselkedésbeli feltételek. Egy további szintje a modellnek, ha ezek kiegészülnek azokkal a jogi, társadalmi, földrajzi és közösségi feltételekkel, amelyek mindezt létrehozzák, támogatják és fenntartják. Az FKM-ben a következö nyelvi megszorítások érvényesek.

a) A nyelvek használata (beleértve a nyelven belüli változatokat) a nyelvválasztási szituációk és a beszélők generációi szerint is fenntartható.

b) A nyelvek tudása (beleértve a nyelven belüli változatokat) a használathoz igazodik, így fenntartható. 
c) Mindkét nyelvhez (beleértve a nyelven belüli változatokat) pozitív attitüdök kapcsolódnak.

d) A nyelvi ideológiák mindkét nyelvet (beleértve a nyelven belüli változatokat) és a kétnyelvüséget is támogatják (vö. BORBÉLY 2014: 245-247).

3. Egy kétnyelvü közösség longitudinális vizsgálata. Ebben a részben az FK-t a magyarországi románok egy településén, Kétegyházán, húsz évet magában foglaló három terepmunka adatai alapján tekintjük át (LonBiLing. kutatás, pl. BoRBÉLY 2013, 2014). A román-magyar nyelvcsere folyamatában az FK vizsgálata egy skála, a fenntartható kétnyelvüség skála (FKS) bevezetésével történik meg (vö. BORBÉLY 2015). Az FKS a kétegyházi közösség nyelvcserehelyzetében 19902010-ben tapasztalt nyelvi és etnikai identitásbeli sajátosságokra épül. (Egy másik közösségben az FKS-t úgy kell kialakítani, hogy a vizsgálandó közösség sajátosságaira épüljön, és hogy érvényességét itemanalízissel is alá lehessen támasztani, ahogyan ez vizsgálatunkban is megtörtént.) Az adatok a román-magyar kétnyelvü közösség nyelvi körülményeihez adaptált szociolingvisztikai interjú (vö. LABOV 1988; BORBÉLY 2001) egységeiből lettek kigyüjtve (nyelvhasználati interjú és irányított beszélgetés), és olyan kétnyelvü személyektől származnak, akikkel három alkalommal $(1990$ = T1, 2000/2001 = T2, 2010/2011 = T3) román nyelvü vizsgálatot végeztem. A feldolgozásra kerülö, 91 adatközlőtől nyert 181 megfigyelés (ez a T1/T2/T3 minta) úgy alakult ki, hogy 34 adatközlő egyszer, 24 adatközlő kétszer, 33 adatközlő pedig háromszor lett kikérdezve (ez utóbbiak a T123 minta). Az adatközlök az életkor, a nem és az iskolázottság szerint szisztematikusan lettek kiválasztva. (A folyamatosan változó, instabil kétnyelvü közösség kutatásakor a populáció nem egyértelmúen határozható meg, ami a mintavétel módszerét behatárolja.)

Az FKS kialakításához felhasznált 13 nyelvszociológiai változó elsősorban a román és a magyar nyelvre irányult, pontosabban bizonyos nyelvhasználati színterek (szituációk) nyelvválasztására, a nyelvekre vonatkozó attitüdökre és a román nyelvtudásra; másodsorban a román nemzeti identitás felvállalására. A feltett kérdésekre (pl. 1a: Házastársával milyen nyelven beszél?) kapott válaszok kódértékei: (1) románul; (2) románul és magyarul; (3) magyarul voltak. Mivel ezen értékek átlagolva lettek, az eredményeket mindig úgy kell értelmezni, hogy minél jobban közelítenek az átlagok az 1-es értékhez, annál inkább jellemzi az adatközlöt „románságának” - nyelvszociológiai változók szerinti - megőrzése és ezáltal a fenntartható kétnyelvűség. Ugyanilyen háromszintủek a válaszok az identitásra és az attitüdökre vonatkozó változóknál is. A nyelvtudás változónál az ötfokú értékskálát lineáris transzformációval hasonló skálára hoztuk. Itt tehát az 1-es az FKS legmagasabb szintjének értéke, a 2-es az FKS közepes szintjének értéke és a 3-as az FKS legalacsonyabb szintjének értéke. A 181 longitudinális megfigyelés FKS tételeinek átlagértéke az FKS index. Minden megfigyelés rendelkezik tehát egy FKS indexszel. Ebben a vizsgálatban is ugyanúgy, mint az előző, MaBiLing. kutatásban az FK szerinti sorba rendezés történik, de ebben az esetben nem közösségeket, hanem egy közösség tagjait rendezzük sorba: a nyelvszociológiai változókra vonatkozó válaszaik kódértékéből nyert FKS index szerint. A továbbiakban 
a két tizedes pontosságúra kerekített FKS indexen, a megfigyelések sorrendjének értelmezését technikailag megkönnyítendö, hat szintet (övezetet) definiáltunk a 181 FKS index sorba rendezésekor: $1 .=1-1,33 ; 2 .=1,36-1,64 ; 3 .=1,67-2 ; 4$. $=$ $2,01-2,33 ; 5 .=2,36-2,66 ; 6 .=2,67-3$. Ennek megfelelően az 1-3. övezetbe került megfigyelésekre a kétnyelvüség fenntartása a (leginkább) jellemző, illetőleg a 4-6. övezetbe került megfigyelésekre a kétnyelvüség fenntartása kevésbé, illetve (egyáltalán) nem jellemző. A statisztikai elemzések a ROPstat programcsomaggal (VARGHA 2008; VARGHA-TORMA-BERGMAN 2015) készültek. A 181 FKS index hat övezet szerinti eloszlása mutatja, hogy a skála alkalmas a T1/T2/T3 mintát a kiválasztott nyelvszociológiai változók szerint rendezni: az FKS1-be 36, az FKS2-be 41, az FKS3-ba 42, az FKS4-be 27, az FKS5-be 24 és az FKS6-ba 11 megfigyelés került (vö. 3. lábjegyzet).

Azt a vizsgálati problémát járjuk körül, hogy mi jellemzi azokat az adatközlöket, akik az FKS-en húsz év alatt nem kerültek az 1-3. övezetböl egy másik övezetbe. Ha ugyanis az FKS indexük alapján mindhárom időmetszetben ugyanabba az övezetbe kerülnek, ez azt jelenti, hogy ezekre az adatközlőkre a román-magyar nyelvcsere folyamatában az FK konstans. A kérdés az, hogy miben különböznek ezek az adatközlők a többiektől.

A T123 mintában a 33-ból csupán 5 adatközlőnek az FK indexe került az FKS 1-3. övezetébe úgy, hogy mindhárom időpontban ugyanabban maradt is meg. Az 5 adatközlő közül az FKS indexe alapján 1 személy az FKS1 és 2-2 az FKS2, illetve FKS3 övezetbe került. A nyelvszociológiai eredmények a nyelvhasználati interjúk adataiból lettek feldolgozva. A 3 időpontban készült 15 irányított beszélgetésből nyert adatokból az is kideríthető volt, hogy miért éppen ezt az 5 adatközlőt jellemzi konstansan az FK. Ezek: 1. erős (rokoni, munkaköri) Romániához füződő kapcsolatok, 2. a román nyelven múködő ortodox egyházban aktív tagság, 3. pozitív attitüd a közösségében használt román nyelvváltozatokhoz és 4. pozitív vélemény a kétnyelvüségről és nyelvi jelenségeiről. A mindhárom időmetszetben az FKS1 övezetbe került adatközlö ifjúkora óta ortodox templomi énekes. Munkája során naponta került kapcsolatba romániai román kollégákkal, ezáltal fejlesztette román nyelvi tudását, melyhez kétnyelvü szótárt és egyéb román nyelvü könyveket is vásárolt. A kétnyelvüek magyar szavára is románul válaszol. A kétegyházi román nyelvet értékeli, édesanyja beszédét magnóra is rögzítette, viszont a magyar eredetủ kétegyházi román szavakat puristaként minősíti, erre példát is ad. A kétegyháziak szerinte nem helyesen beszélnek, ha például ezt mondják: serepeli < szerepelni $(\mathrm{T} 1 / 42)^{4}$. Az FKS2 övezetbeli mindkét adatközlö erősen kötődik Romániához nagyszámú ottani rokonságságuk miatt: „Aradon legalább tizenötször voltam” (T1/8); „Nagyon gyakran, évente úgy háromszor megyek" (T1/84). Továbbá az ortodox templom aktív tagjai, és kétegyházi munkahelyükön románokkal is tudtak románul beszélni. Mindketten a románokkal románul beszélnek: „Románul beszélek vele, mert román” (T1/84). A kétegyházi románok

\footnotetext{
${ }^{4}$ Az adatközlők beazonosítása a terepmunka és az interjúk sorrendje szerint történik. A továbbiakban idézett interjúrészleteket magyar fordításban adom meg. A nagybetűvel átírt interjúrészek a magyar kódváltásokat jelzik.
} 
beszédét összehasonlítva a Romániában beszélt román nyelvvel egyikőjük egy, az általánosan ismert véleménnyel ellentétes dolgot fogalmaz meg: „ÁÁÁ, SZERINTEM, mi jobban beszélünk, mint ők”. Bár azt is hozzáteszi: „ők perfektül beszélnek" (T1/84). Az FKS3 övezetbe került két adatközlő is erősen kötődik Romániához. Egyikőjük munkahelyén szintén kapcsolatban állt romániai román kollégákkal, másikuk édesanyja romániai születésủ és nagyon pozitív attitüd füzi Romániához: „Romániában nagyon jól érzem magam, [...] ők kulturáltabban beszélnek, mint a magyarországi románok" (T1/1). Az ortodox egyházhoz nem kötődnek, és egyikük házastársa magyar. Összességében a három FK övezetbe tartozó adatközlő közös vonása az átlagon felüli romániai kapcsolat és pozitív attitüd a romániai kultúra irányában. A kétegyházi román-magyar közösségben ez nem mindenkire jellemző (nincs mindenkinek romániai rokona, illetve munkája nem köti oda). Ennek alátámasztásaként említem meg például az FKS indexe alapján az FKS5 övezetbe került adatközlő példáját, aki Romániában csak egyszer járt, ${ }^{5}$ s erről csak negatív emlékei vannak (T2), illetve ottani emlékeit elhallgatja (T3). Emellett a kétegyházi román nyelvváltozatot nem értékeli, és magyarul beszél a román-magyar kétnyelvűekkel is, továbbá a kétnyelvűség jelenségeit (pl. kódváltás) negatívan minősíti (T1/18).

4. Összegzés. A MaBiLing. kutatás eredményeire épülő FKM világossá teszi, hogy az FK megvalósulásához a kétnyelvü közösségben fenn kell tartani az e gyensúlyt két nyelv között, generációkon át (vö. 1. ábra). A LongBiling. kutatás eredményei pedig ezt a következtetést erősítették meg, immár az egyének viszonylatában. Bizonyossá téve, hogy leginkább az átlagosnál erősebb romániai kapcsolatokkal magyarázható a saját nyelv gyakoribb választása, jobb ismerete, valamint a kétnyelvüséghez, a saját nyelvhez és változataihoz kapcsolt pozitív attitüdök. A két kutatás elemzései segítségével sikerült alátámasztani, hogy az átmeneti kétnyelvüségben, mely végső esetben nyelvcserével zárulhat, egyrészt kimutatható az FK, másrészt hangsúlyt kapott az is, hogy az FK - és végső soron a stabil kétnyelvüség (1. SCHIFFMAN megállapításait) - miért olyan nehezen realizálható jelenség. A két kutatás eredményeire támaszkodva a közösségek kétnyelvüségének időbeli dinamikáját az eddigi ismereteket kiegészítve a 2. ábra foglalja össze.

COUPLAND (2007: 50-51) egy, a szociolingvisztikai szakirodalomban gyakran idézett LABOV-tanulmány (1972: 1-42) ${ }^{6}$ lényegét a következőképpen fogalmazza meg: azt mutatja meg, hogy a nyelvi variabilitás a társadalmi változások ellenállásaként hogyan tud múködni. Felhasználva ezt a következtetést általánosabban, az FK fogalomkörének felvázolásakor az fogalmazható meg, hogy az FK egyenlő a társadalmi változások nyomása ellen kialakult, illetve kialakított ellenállással. Ennek az ellenállásnak mindenképpen lehetséges egy természetes megvalósulása (1. a LongBiLing. kutatás eredményeit), de feltételezhető egy tudatosa(bba)n kialakított formája is (1. a MaBiLing. kutatás eredményeit).

${ }^{5}$ A T1-es minta 60 adatközlöjéből Romániában 50-en jártak. Közülük 23-an csupán egyszer, évente egyszer 10-en jártak, szintén 10-en évente kétszer-háromszor, és ennél is gyakrabban 7-en jártak Romániában (BORBÉLY 2001: 284).

${ }^{6} \mathrm{Az}$ (ai) ejtését vizsgáló kutatás a Martha’s Vineyard (Massachusetts, USA) szigeten készült. 


\section{2. ábra}

A kétnyelvűség időbeli dinamikája

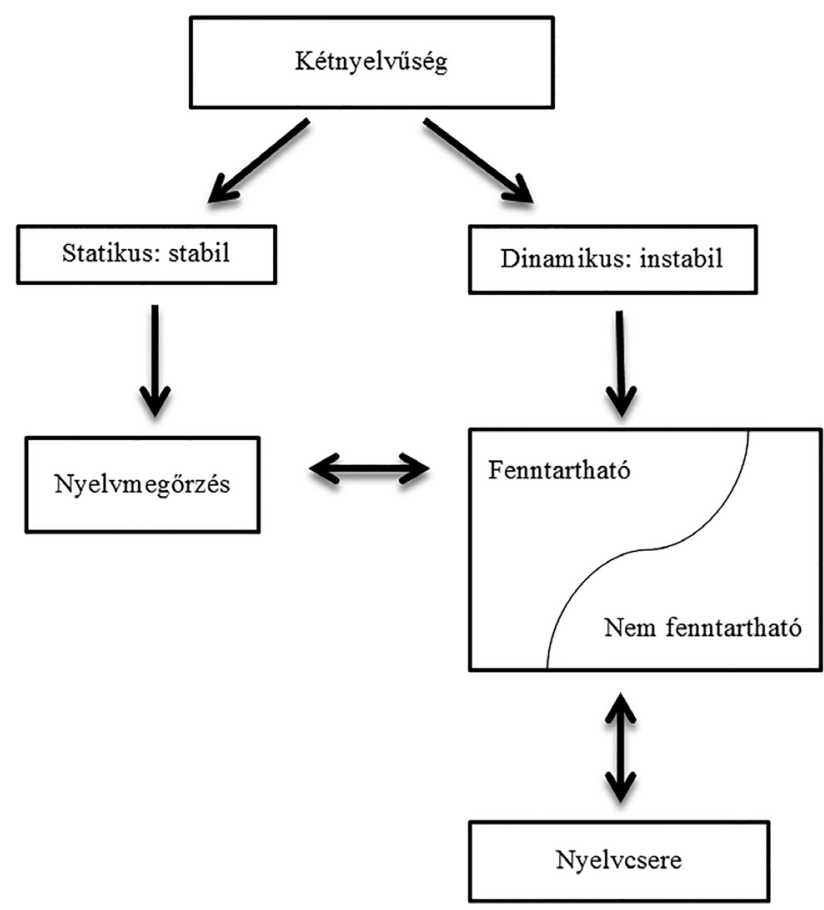

Kulcsszók: fenntartható kétnyelvüség, nyelvcsere, magyarországi kétnyelvü közösségek, szociolingvisztikai kutatások, longitudinális módszer, csoport-összehasonlító módszer.

\section{Hivatkozott irodalom}

BARTHA CSILLA 1993. Egy amerikai magyar közösség nyelvhasználatának szociolingvisztikai megközelitése. Kandidátusi értekezés. MTA, Budapest.

BARTHA CSILLA 2003. A nyelvi másság dimenziói: a kisebbségi nyelvek megőrzésének lehetőségei - egy országos szociolingvisztikai-kétnyelvüségi vizsgálatról. In: HAJDÚ MiHÁLY - KESZLER BORBÁLA szerk., Köszöntö Kiss Jenö 60. születésnapjára. ELTE Magyar Nyelvtudományi és Finnugor Intézet - Magyar Nyelvtudományi Társaság, Budapest. 304-311.

BorbÉLY ANNA 2001. Nyelvcsere. Szociolingvisztikai kutatások a magyarországi románok közösségében. Készült az MTA Nyelvtudományi Intézetének Élőnyelvi Osztályán, Budapest.

BORBÉLY ANNA 2013. Nyelvcsere és nemzetiségi identitás: elméleti kérdések és kutatási módszerek. In: KonTRA MiKLós - NÉMETH MiKLÓs - SinKOVICS BALÁzS szerk., 
Elmélet és empíria a szociolingvisztikában (Válogatás a 17. Élőnyelvi Konferencia - Szeged, 2012. augusztus 30. - szeptember 1. - elöadásaiból.) Gondolat Kiadó, Budapest. 101-118.

BORBÉlY ANNA 2014. Kétnyelvüség - Variabilitás és változás magyarországi közösségekben. L’Harmattan Könyvkiadó, Budapest.

BORBÉLY ANNA 2015. Egyéni fenntartható kétnyelvüség. Előadás kézirata. MTA Nyelvtudományi Intézet, Budapest.

COUPLAND, NiKOLAS 2007. Style. Language variation and identity. Cambridge University Press, Cambridge.

DORIAN, NANCY C. 2004. The bilingual and multilingual community. In: BHATIA, TEJ K. Ritchie, William C. ed., The Handbook of Bilingualism. Blackwell Publishing, Malden (MA, USA) - Oxford (UK) - Victoria (Australia). 385-405.

FENYVESI, ANNA 1995. Language contact and language death in an immigrant language: The case of Hungarian. Department of Linguistics, University of Pittsburgh, Pittsburgh.

Ferguson, Charles A. 1959. Diglossia. Word 15: 325-340. http://dx.doi.org/10.1080/0[-] 0437956.1959.11659702

FiSHMAN, JOSHUA A. 1968. Sociolinguistic perspective on the study of bilingualism. Linguistics 39: 21-49. http://dx.doi.org/10.1515/ling.1968.6.39.21

FISHMAN, JOSHUA A. 1971. The sociology of language: An interdisciplinary social science approach to language in society. In: FISHMAN, JoshuA A. ed., Advances in the sociology of language. Mouton, The Hague. 217-404.

GAL, SUSAN 1979. Language shift: Social determinants of linguistic change in bilingual Austria. Academic Press, New York.

Hamers, Josiane F. - Blanc, Michel H. A. 1989. Bilinguality and Bilingualism. Cambridge University Press, Cambridge.

KISS JENŐ 1994. Kétnyelvüség, kettősnyelvüség és diglosszia. Magyar Nyelv 90: 81-85.

KONTRA MiKLÓS 1990. Fejezetek a South Bend-i magyar nyelvhasználatból. Linguistica series A, Studia et Dissertationes 5. MTA Nyelvtudományi Intézet, Budapest.

LABOV, William 1972. Sociolinguistic Patterns. University of Pennsylvania Press, Philadelphia.

LABOV, WILLIAM 1988. A nyelvi változás és változatok. Egy kutatási program terepmunkamódszerei. Szociológiai Figyelö 4: 22-48.

SCHIFFMAN, HAROLD F. 1993. The balance of power in multiglossic languages: implications for language shift. International Journal of the Sociology of Language 103: 115-148. http://dx.doi.org/10.1515/ijsl.1993.103.115

VARGHA ANDRÁS 2008. Új statisztikai módszerekkel új lehetőségek: a ROPstat a pszichológiai kutatások szolgálatában. Pszichológia 1: 81-103. http://dx.doi.org/10.1556/[-] Pszi.28.2008.1.5

VARGHA ANDRÁS - TORMA BOGLÁRKA - BERgMAN, LARS R. 2015. ROPstat: a general statistical package useful for conducting person-oriented analyses. Journal for Person-Oriented Research 1-2: 87-98. http://dx.doi.org/10.17505/jpor.2015.09

WEINREICH, URIEL 1953. Languages in contact. Findings and problems. Publications of Linguistic Circle of New York 1. Linguistic Circle of New York, New York. 


\section{Sustainable bilingualism}

The paper introduces the concept of sustainable bilingualism (SB), inspired by the results of two empirical sociolinguistic research projects (LongBiLing. and MaBiLing.). The investigations presented here were conducted in the last decade of the past century and the first decade of the present century, and involved the Boyash, German, Roma, Romanian, Serbian and Slovak communities of Hungary. In the course of both projects, SB ordering was performed. In one case, six communities were ordered in terms of SB, and in the other, members of a single community were, on the basis of sociolinguistic data (language choice, proficiency, and attitudes) gleaned from sociolinguistic questionnaires and interviews. As a result of our empirical analyses a model was set up. The Sustainable Bilingualism Model (SBM) is built on the profoundly studied linguistic behaviors such as language choice, proficiency and attitudes, but is also open for additional devices (for example language ideologies, etc. are not studied in the article). In this model languages of bilingual communities must be of equal status in language choice, proficiency, and attitudes. The two projects highlighted the reasons why stable bilingual communities are so rare in general, and they showed how SB can be successfully investigated within unstable bilingualism.

Keywords: sustainable bilingualism, language shift, bilingual communities in Hungary, sociolinguistic research, longitudinal method, the method of group comparisons.

BORBÉLY ANNA

MTA Nyelvtudományi Intézet 